\title{
MODELING THE LEVEL OF REMUNERATION IN Poland
}

\section{MODELOWANIE POZIOMU WYNAGRODZEŃ W Polsce}

\begin{abstract}
Thanks to cash, people can meet their basic existential needs, such as having an apartment or buying clothes and food. The basic source of income generation is gainful employment, for which remuneration is paid. It is the pay is the main subject of this work. On the basis of available sources of work, the focus was on the analysis of remuneration at the Polish level, using the available econometric knowledge. The aim of this paper was to determine the structural parameters of the econometric model, which allowed for appropriate construction of the wage model in Poland taking into account the regional differentiation in the years 2002-2015. The econometric model of wages in Poland, in terms of voivodeship, allowed to describe changes in Polish wages. Based on the results of the estimation of the created econometric model it can be stated that the trend function confirms the upward trend of the studied phenomenon, which is manifested in the increase of the average monthly salary for each voivodship in each year of observation. The increase in the average remuneration for each of the voivodships was at different levels, but very similar in the country and will be characterized by the highest level of fit.
\end{abstract}

\section{STRESZCZENIE}

Środki pieniężne pozyskiwane w formie wynagrodzeń wykorzystywane są w głównej mierze na realizację podstawowych potrzeb egzystencjalnych. Podstawowym źródłem generowania dochodu jest praca zarobkowa, za którą otrzymywane jest wynagrodzenie. To właśnie wynagrodzenie jest głównym przedmiotem niniejszej pracy. 
W opracowaniu skupiono się na analizie wynagrodzenia na poziomie Polski, korzystając z dostępnych źródeł wiedzy ekonometrycznej. Celem niniejszej publikacji było wyznaczenie parametrów strukturalnych modelu ekonometrycznego, co pozwoliło na właściwe skonstruowanie modelu poziomu wynagrodzeń w Polsce z uwzględnieniem zróżnicowania regionalnego w latach 2002-2015. Model ekonometryczny poziomu wynagrodzeń w Polsce w ujęciu wojewódzkim pozwolił na opis zmian polskich wynagrodzeń. Na podstawie wyników estymacji stworzonego modelu ekonometrycznego można stwierdzić, że funkcja trendu potwierdza tendencję wzrostową badanego zjawiska, co objawia się w postaci wzrostu przeciętnego miesięcznego wynagrodzenia dla każdego województwa, w każdym roku obserwacji. Wzrost przeciętnego wynagrodzenia dla każdego z województw był na różnym poziomie, lecz bardzo zbliżonym w skali kraju, charakteryzował się jak najwyższym poziomem dopasowania.

KEYWORDS: salary, change trend, econometric model, Differentiation of wages, KMNK method

SŁow A KuCzowe: wynagrodzenie, model ekonometryczny, trend zmian, zróżnicowanie wynagrodzeń, metoda KMNK

\section{POJĘCIE I ISTOTA WYNAGRODZEŃ}

Wynagrodzenie można najogólniej określić jako zapłatę za podporządkowaną pracę, wykonywaną na rzecz pracodawcy. Może być ono zapłatą za już wykonaną pracę lub za pracę, która została dopiero zlecona i zostanie wykonana przez pracownika w przyszłości (Czajka, 2009). Według definicji ekonomicznych, wynagrodzenie jest ceną pracy, siły roboczej, co jest jednym z elementów czynników produkcji. W tabeli 1 w syntetyczny sposób postarano się przybliżyć terminologię dotyczącą wynagrodzeń.

Wynagrodzenia pełnią kilka silnie ze sobą powiązanych funkcji, które rozpatrywane są nie tylko pod względem ekonomicznym, lecz także społecznym, prawnym i psychologicznym. Niemożliwe jest wyznaczenie najważniejszego z tych aspektów, więc każdy system wynagrodzeń powinien uwzględniać ich funkcje jako całość silnie ze sobą związanych elementów. W dziedzinie ekonomii możemy wyróżnić następujące funkcje płac: motywacyjną, dochodową, rynkową, kosztową oraz społeczną (Borkowska, 2004; Król, Ludwiczyński, 2014).

Istotą funkcji dochodowej jest przeciwdziałanie poszukiwaniu przez pracowników dodatkowych (często nielegalnych) źródeł dochodu, zapobieganie 
zbytniej eksploatacji pracowników przez zbyt dużą intensywność pracy, a także ograniczanie wszelkich konfliktów na tle wynagrodzeń. Znaczenie tej funkcji jest w dużym stopniu uzależnione od wysokości wynagrodzenia, kosztów utrzymania oraz liczby osób w gospodarstwie domowym pracownika. Wpływ na dochodową funkcję wynagrodzenia mają także czynniki makroekonomiczne (w postaci wysokości płacy minimalnej, badań minimalnego koszyka dóbr). Najważniejszym miernikiem wartościującym funkcję dochodową jest płaca realna ustalana na podstawie przeciętnego miesięcznego wynagrodzenia netto, odpowiednio skorygowanego o wskaźnik wzrostu cen towarów i usług konsumpcyjnych wg obliczeń Głównego Urzędu Statystycznego (Sekuła, 2013).

Tabela 1.

Wybrane terminy dotyczące wynagrodzenia

\begin{tabular}{|c|c|c|}
\hline Lp. & Nazwa pojęcia & Definicja \\
\hline 1. & Ekwiwalent & Równoważnik otrzymywany w formie pieniężnej lub w naturze \\
\hline 2. & Gaża & Stałe wynagrodzenie za pracę, uposażenie w niektórych zawodach \\
\hline 3. & Pensja & Stała płaca miesięczna, roczna, stałe wynagrodzenie \\
\hline 4. & Płaca & Gotówkowa postać wynagrodzenia \\
\hline 5. & Pobory & Wynagrodzenie otrzymywane regularnie \\
\hline 6. & Uposażenie & Stała pensja miesięczna - dotycząca służb mundurowych \\
\hline 7. & Wynagrodzenie & Płatność za pracę wykonywaną przez pracownika \\
\hline 8. & Zapłata & Uiszczenie należności za coś \\
\hline 9. & Zarobek & Wynagrodzenie za wykonaną pracę, a także zysk z transakcji \\
handlowej
\end{tabular}

Źródło: opracowanie własne na podstawie Z. Sekuła, Struktury wynagradzania pracowników, Wolters Kluwer Polska, Warszawa 2013, s. 17-19.

Wysokość wynagrodzenia są uzależnione od sytuacji na rynku pracy (funkcja rynkowa). Nadwyżka podaży nad zapotrzebowaniem na pracę może skutkować niedopłacaniem pracy, czego konsekwencją jest brak ekwiwalentności pracy i zapłaty za nią. 
Wysokość i znaczenie funkcji kosztowej są inne dla każdej organizacji. Zależą one od typu organizacji, obowiązujących w danym kraju lub regionie obciążeń podatkowych, rodzaju pracy i udziału pracy żywej w tworzonych produktach. Koszty pracy są dla wielu organizacji najważniejszym kryterium lokalizacji nowych inwestycji lub przeniesienia obecnych, zlokalizowanych w miejscach, gdzie są one wyższe.

Społeczna funkcja płac opiera się na tym, że wynagrodzenie otrzymywane za wykonaną pracę jest podstawową formą zaspokojenia potrzeb pracownika i jego rodziny. Wynika z niej także, że pracownik i pracodawca są wobec siebie równorzędni, jedna i druga strona posiada prawa i uprawnienia, a także obowiązki wynikające $\mathrm{z}$ wiążącej ich umowy. Poziom płacy ma także duże znaczenie dla uznania, prestiżu i rangi danego zawodu (Sekuła, 2013). Funkcja społeczna wynagrodzenia wiąże się także z satysfakcją z wykonywanych działań, realizacji własnych celów i pragnień przez pracę lub niechęci do jej wykonywania i zmęczenia pracą. Na jej duże znaczenie ma także wpływ roli człowieka w procesie wytwórczym. To człowiek jest odpowiedzialny za efekty pracy. Wszystko, co wiąże się z pracownikiem, ma prawo być nazywane wymiarem społecznym (Jacukowicz, 2010).

\section{ZALOŻENIA METODYCZNE}

Celem niniejszej pracy jest stworzenie modelu ekonometrycznego poziomu wynagrodzeń na podstawie zmiennych uzyskanych z danych statystycznych pobranych z Banku Danych Lokalnych Głównego Urzędu Statystycznego. Dane o wynagrodzeniach podane są w ujęciu brutto, tj. łącznie z zaliczkami na poczet podatku dochodowego od osób fizycznych oraz ze składkami na obowiązkowe ubezpieczenia społeczne (emerytalne, rentowe i chorobowe) płaconymi przez ubezpieczonego pracownika (tabela 2). 


\begin{tabular}{|c|c|c|c|c|c|c|c|c|c|c|c|c|c|c|c|c|c|c|c|}
\hline & 류 & 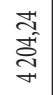 & 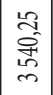 & 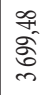 & $\begin{array}{l}8 \\
8 \\
0 \\
\infty \\
m\end{array}$ & $\begin{array}{l}\frac{0}{\hat{a}} \\
\stackrel{2}{m} \\
m\end{array}$ & $\begin{array}{l}\text { ूू } \\
\text { ळे } \\
\text { mे }\end{array}$ & $\begin{array}{l}\text { 웅 } \\
\text { 音 } \\
\text { in }\end{array}$ & 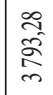 & $\begin{array}{c}\widetilde{\sigma} \\
\widetilde{\sim} \\
\tilde{\sigma} \\
\tilde{m}\end{array}$ & 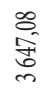 & $\begin{array}{l}\stackrel{\cong}{\approx} \\
\underset{\sigma}{\approx}\end{array}$ & 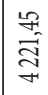 & 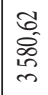 & 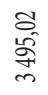 & $\begin{array}{l}\text { त् } \\
\text { ô } \\
\text { 命 }\end{array}$ & $\begin{array}{l}\infty \\
\delta \\
\delta \\
\tilde{\Omega} \\
m\end{array}$ & \begin{tabular}{l}
$\infty$ \\
$\infty$ \\
0 \\
0 \\
\hdashline \\
$z$
\end{tabular} & \\
\hline & 록 & 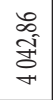 & 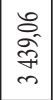 & $\begin{array}{l}0 \\
0 \\
0 \\
0 \\
0\end{array}$ & $\stackrel{\text { I }}{\text { I }}$ & $\begin{array}{l}\tilde{6} \\
\infty \\
0 \\
0 \\
m\end{array}$ & 胥 & $\begin{array}{l}\overrightarrow{2} \\
\stackrel{2}{\sigma} \\
\text { హे }\end{array}$ & 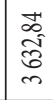 & 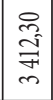 & 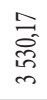 & 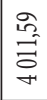 & 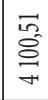 & 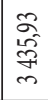 & 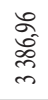 & $\begin{array}{l}\text { b. } \\
\text { s. } \\
\text { rn }\end{array}$ & $\begin{array}{l}\text { त् } \\
\text { ôd } \\
\text { d. }\end{array}$ & $\begin{array}{l}\text { oे } \\
\text { ळे } \\
\text { के }\end{array}$ & \\
\hline & $\stackrel{\widetilde{\pi}}{\tilde{\pi}}$ & $\begin{array}{l}8 \\
\infty \\
0 \\
\infty \\
\infty \\
m\end{array}$ & $\begin{array}{l}g \\
\text { a } \\
\text { in } \\
m\end{array}$ & \begin{tabular}{|c|}
$\sigma$ \\
$\infty$ \\
$\infty$ \\
$\infty$ \\
$\infty$ \\
$m$
\end{tabular} & $\underset{\sim}{\sim}$ & $\begin{array}{l}\text { ్ } \\
\text { ô } \\
\text { nn }\end{array}$ & 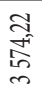 & 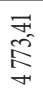 & $\begin{array}{l}\text { 우 } \\
\text { f } \\
\text { f }\end{array}$ & 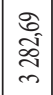 & $\begin{array}{l}\text { F } \\
\text { శ్ } \\
\text { f }\end{array}$ & $\begin{array}{l}\mathcal{Z} \\
\stackrel{\sim}{0} \\
\infty \\
\infty\end{array}$ & 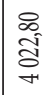 & 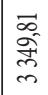 & 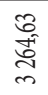 & 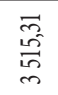 & $\begin{array}{l}\approx \\
\approx \\
\tilde{\Omega} \\
\tilde{n} \\
m\end{array}$ & 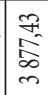 & \\
\hline & ్ㅗㄱ & $\begin{array}{c}\tilde{a} \\
\text { aे } \\
\text { n. }\end{array}$ & $\begin{array}{l}\vec{m} \\
\cong \\
\vec{m} \\
\vec{m}\end{array}$ & 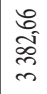 & 令 & 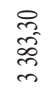 & 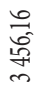 & \begin{tabular}{l}
$\infty$ \\
$\stackrel{2}{2}$ \\
$\hat{\sigma}$ \\
\multirow{\sigma}{*}{}
\end{tabular} & 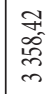 & $\begin{array}{l}2 \\
\widetilde{2} \\
\stackrel{\Omega}{n} \\
\approx\end{array}$ & 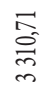 & 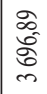 & $\begin{array}{c}2 \\
-1 \\
2 \\
0 \\
0 \\
0\end{array}$ & 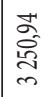 & $\begin{array}{l}\hat{y} \\
\hat{n} \\
\text { ñ }\end{array}$ & 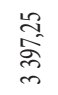 & 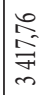 & 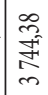 & \\
\hline 3 & $\overline{\bar{乛}}$ & $\begin{array}{l}\stackrel{2}{N} \\
\stackrel{2}{\infty} \\
i m \\
m\end{array}$ & 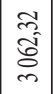 & 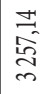 & ๘̊ & $\begin{array}{l}\text { 命 } \\
\text { 产 } \\
\text { m. }\end{array}$ & $\begin{array}{l}\text { 周 } \\
\text { స్ }\end{array}$ & \begin{tabular}{l}
8 \\
$\stackrel{0}{0}$ \\
\multirow{8}{*}{} \\
$\stackrel{7}{+}$
\end{tabular} & $\begin{array}{l}\infty \\
\stackrel{2}{\sim} \\
\underset{\sim}{\sim} \\
\sim\end{array}$ & 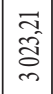 & $\begin{array}{l}\stackrel{n}{2} \\
\infty 0^{-1} \\
\stackrel{n}{m}\end{array}$ & \begin{tabular}{|l|}
9 \\
0 \\
0 \\
2 \\
0 \\
0
\end{tabular} & 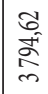 & $\begin{array}{l}\vec{a} \\
\frac{1}{2} \\
\tilde{m}\end{array}$ & $\begin{array}{l}\hat{\sigma} \\
\stackrel{2}{\sigma} \\
\stackrel{m}{\sigma}\end{array}$ & $\begin{array}{l}\underset{\mathbb{N}}{F} \\
\text { స్ }\end{array}$ & 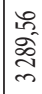 & 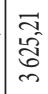 & \\
\hline 곤 & 을 & 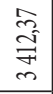 & $\begin{array}{l}0 \\
0 \\
0 \\
\sigma \\
\sim\end{array}$ & $\begin{array}{l}8 \\
8 \\
2 \\
\\
\end{array}$ & 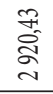 & 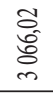 & 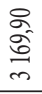 & \begin{tabular}{l}
$\stackrel{2}{2}$ \\
$\stackrel{2}{2}$ \\
\multirow{7}{*}{}
\end{tabular} & $\frac{2}{\stackrel{2}{m}}$ & 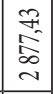 & 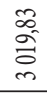 & 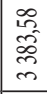 & $\begin{array}{l}a \\
0 \\
0 \\
\tilde{d} \\
m \\
m\end{array}$ & 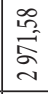 & 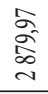 & 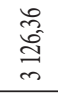 & 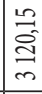 & 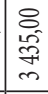 & \\
\hline 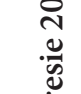 & ڤ્సે & $\begin{array}{l}\text { 㥕 } \\
\text { 令 } \\
\text { 心 }\end{array}$ & $\begin{array}{l}0 \\
\hat{\sigma} \\
\infty \\
\infty \\
v \\
\end{array}$ & 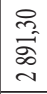 & 今ิ & $\begin{array}{l}B \\
\text { 今0 } \\
\infty \\
\sim \\
0\end{array}$ & $\begin{array}{l}\vec{E} \\
\text { 홍 } \\
\text { o }\end{array}$ & \begin{tabular}{l}
8 \\
\multirow{5}{7}{} \\
$\Rightarrow$
\end{tabular} & 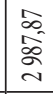 & 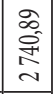 & $\begin{array}{l}\infty \\
\infty \\
0 \\
\infty \\
\sim \\
\sim\end{array}$ & 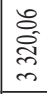 & 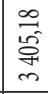 & 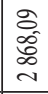 & 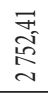 & 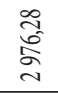 & $\begin{array}{l}\overrightarrow{\vec{n}} \\
\vec{\Xi} \\
\text { r }\end{array}$ & \begin{tabular}{|l}
$\infty$ \\
$\infty$ \\
$m$ \\
$m$ \\
$m$ \\
$m$
\end{tabular} & \\
\hline $\begin{array}{l}\frac{1}{0} \\
3 \\
3\end{array}$ & ఫ્సి & $\begin{array}{l}\infty \\
\infty \\
\omega \\
\omega \\
m\end{array}$ & $\begin{array}{l}\vec{a} \\
\vec{a} \\
\vec{\sigma} \\
\vec{v}\end{array}$ & $\underset{⿱ 丶}{\stackrel{2}{\Sigma}}$ & $\tilde{E}$ & $\begin{array}{l}\infty \\
\stackrel{\infty}{2} \\
\stackrel{5}{0} \\
\sim\end{array}$ & $\begin{array}{l}\tilde{b} \\
\tilde{\delta}\end{array}$ & 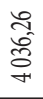 & $\begin{array}{l}\underset{\mathbb{Z}}{\tilde{\Omega}} \\
\stackrel{0}{\infty} \\
\sim\end{array}$ & \begin{tabular}{c}
$\simeq$ \\
\multirow{\forall}{*}{} \\
$\sim$ \\
$\sim$
\end{tabular} & 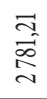 & $\frac{R}{\sigma}$ & $\begin{array}{l}\text { aे } \\
\text { ô } \\
\tilde{\sigma} \\
\tilde{\sigma}\end{array}$ & 空 & $\begin{array}{l}\stackrel{2}{2} \\
\stackrel{2}{0} \\
\sim \\
\sim\end{array}$ & $\begin{array}{l}\overrightarrow{0} \\
0 \\
0 \\
\infty \\
\sim\end{array}$ & $\begin{array}{l}8 \\
0 \\
0 \\
0 \\
\sim\end{array}$ & $\begin{array}{l}\infty \\
0 \\
0 \\
0 \\
0 \\
\infty \\
m\end{array}$ & \\
\hline $\begin{array}{l}\bar{N} \\
\text { Dे } \\
0 \\
3\end{array}$ & ఫ్రి & $\begin{array}{l}8 \\
8 \\
0 \\
0 \\
\sim\end{array}$ & $\begin{array}{c}\stackrel{\Xi}{a} \\
\underset{+}{f} \\
\sim\end{array}$ & 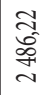 & 今ે & $\begin{array}{l}\stackrel{8}{0} \\
\stackrel{8}{\stackrel{\leftrightarrow}{\sim}}\end{array}$ & $\begin{array}{l}\mathbb{Z} \\
\underset{0}{0} \\
\stackrel{\sim}{2}\end{array}$ & 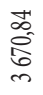 & 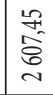 & 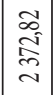 & 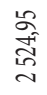 & 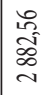 & $\begin{array}{l}\widetilde{\approx} \\
\tilde{\sigma} \\
\approx \\
\approx\end{array}$ & 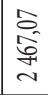 & $\begin{array}{l}8 \\
8 \\
0 \\
\sim \\
\sim\end{array}$ & 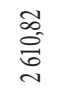 & $\begin{array}{l}\tilde{\infty} \\
\tilde{n} \\
\tilde{2} \\
\sim\end{array}$ & $\begin{array}{l}\text { t. } \\
\underset{0}{0} \\
\sim \\
\sim\end{array}$ & \\
\hline$\frac{2}{3}$ & ઠి. & $\begin{array}{l}\overrightarrow{0} \\
\stackrel{-}{5} \\
\text { v }\end{array}$ & $\begin{array}{l}\infty \\
\infty \\
0 \\
0 \\
\sim \\
0\end{array}$ & 离 & 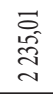 & 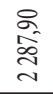 & $\overrightarrow{\vec{q}}$ & $\begin{array}{l}\stackrel{2}{\Rightarrow} \\
\vec{m} \\
m\end{array}$ & $\begin{array}{l}\frac{N}{\sigma} \\
\stackrel{\sigma}{\sim} \\
\sim\end{array}$ & $\begin{array}{l}\hat{2} \\
\stackrel{2}{\sigma} \\
\approx\end{array}$ & 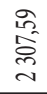 & 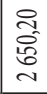 & 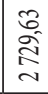 & $\begin{array}{l}8 \\
0 \\
0 \\
0 \\
\sim\end{array}$ & $\begin{array}{l}\underset{2}{2} \\
\stackrel{\infty}{\sim} \\
\underset{\sim}{\sim}\end{array}$ & 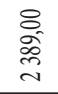 & $\infty$ & 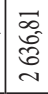 & \\
\hline$\stackrel{0}{\underline{Z}}$ & 농 & 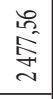 & 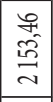 & \begin{tabular}{|l|}
$\infty$ \\
$\infty$ \\
$\infty$ \\
$\sim$ \\
\end{tabular} & $\underset{\sim}{\stackrel{2}{\mathbb{J}}}$ & $\begin{array}{l}\text { ㅇ } \\
\text { of } \\
\infty \\
\sim \\
\sim\end{array}$ & $\underset{7}{ }$ & $\begin{array}{l}\vec{\Delta} \\
\text { 令 } \\
\text { n }\end{array}$ & 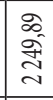 & 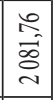 & 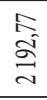 & $\begin{array}{l}\stackrel{2}{\sim} \\
\underset{\vec{\sigma}}{\sim} \\
\sim\end{array}$ & 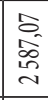 & \begin{tabular}{|l}
$\frac{2}{\sigma}$ \\
$\stackrel{5}{\sigma}$ \\
$\sim$
\end{tabular} & $\begin{array}{l}\stackrel{\partial}{\sigma} \\
\stackrel{\sigma}{\sigma}\end{array}$ & 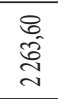 & $\begin{array}{l}2 \\
2 \\
\hat{\sigma} \\
\tilde{\sigma} \\
\sim\end{array}$ & 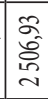 & \\
\hline$\cdot \stackrel{\frac{\pi}{3}}{3}$ & ఫ્రે & 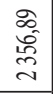 & $\begin{array}{c}0 \\
2 \\
o \\
o \\
0 \\
\sim\end{array}$ & 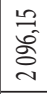 & 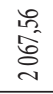 & $\begin{array}{l}0 \\
\approx \\
\approx \\
\approx \\
\approx\end{array}$ & $\overrightarrow{\widetilde{\sigma}}$ & 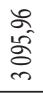 & 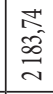 & $\begin{array}{c}0 \\
2 \\
0 \\
0 \\
0 \\
\sim\end{array}$ & $\begin{array}{l}\stackrel{2}{2} \\
\stackrel{0}{0} \\
\sim\end{array}$ & 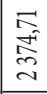 & 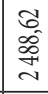 & 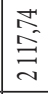 & 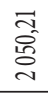 & 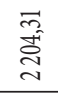 & 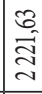 & 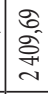 & \\
\hline 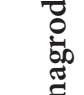 & రిశ్రి & $\begin{array}{l}\infty \\
\stackrel{\infty}{\approx} \\
\stackrel{\approx}{\sim} \\
\sim\end{array}$ & $\begin{array}{l}2 \\
\stackrel{2}{0} \\
0 \\
0 \\
\text { v }\end{array}$ & 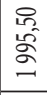 & ริ & 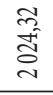 & $\begin{array}{l}\vec{a} \\
\stackrel{0}{0}\end{array}$ & 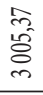 & 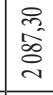 & 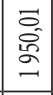 & 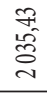 & $\begin{array}{l}\text { 己 } \\
\text { 怘 } \\
\sim\end{array}$ & $\begin{array}{l}\tilde{z} \\
\text { s. } \\
\stackrel{\sim}{\sim} \\
\sim\end{array}$ & 胥 & $\underset{\sim}{\stackrel{\overbrace{}}{8}}$ & $\begin{array}{l}\stackrel{2}{\approx} \\
\underset{\Xi}{\sim}\end{array}$ & 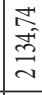 & $\begin{array}{l}0 \\
\stackrel{\vec{f}}{2} \\
\sim\end{array}$ & \\
\hline$\hat{\xi}$ & ઠิં & 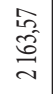 & $\begin{array}{c}2 \\
\tilde{2} \\
\hat{\Omega} \\
\underline{-}\end{array}$ & $\begin{array}{l}\vec{\sigma} \\
\vec{E} \\
\vec{E}\end{array}$ & $\begin{array}{l}\text { 芯 } \\
\text { 次 }\end{array}$ & $\begin{array}{l}\text { तु } \\
\text { ठ̊ }\end{array}$ & ळे & 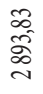 & $\begin{array}{l}\text { ळे } \\
\text { ठे }\end{array}$ & 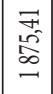 & \begin{tabular}{l}
8 \\
8 \\
0 \\
2 \\
\hdashline
\end{tabular} & 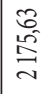 & 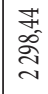 & $\begin{array}{l}\frac{2}{2} \\
\stackrel{5}{5} \\
\underline{-}\end{array}$ & $\begin{array}{l}\text { ूे } \\
\text { के }\end{array}$ & $\begin{array}{l}\infty \\
\stackrel{2}{\Omega} \\
\stackrel{2}{\circ} \\
\sim\end{array}$ & 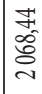 & 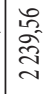 & \\
\hline 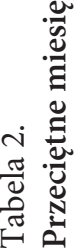 & $/$ & 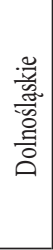 & 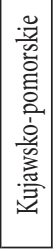 & 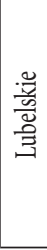 & 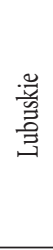 & 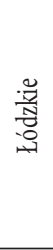 & 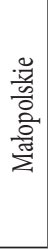 & 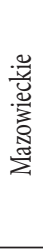 & 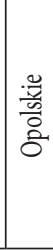 & 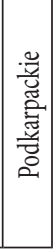 & 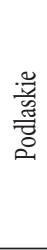 & 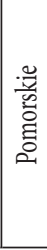 & 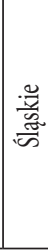 & 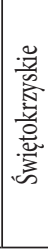 & 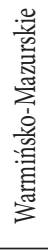 & 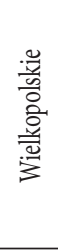 & 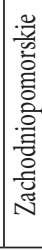 & $\frac{\vec{g}}{\mathrm{~g}}$ & 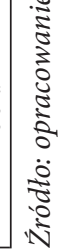 \\
\hline
\end{tabular}


W celu pełniejszego zaprezentowania zmian poziomu wynagrodzeń w Polsce wynagrodzenia w latach 2005 i 2015 przedstawiono w formie graficznej (rysunki 1 i 2).

\section{Rysunek 1.}

Poziom wynagrodzeń w Polsce w 2005 r.

Źródło: opracowanie własne.

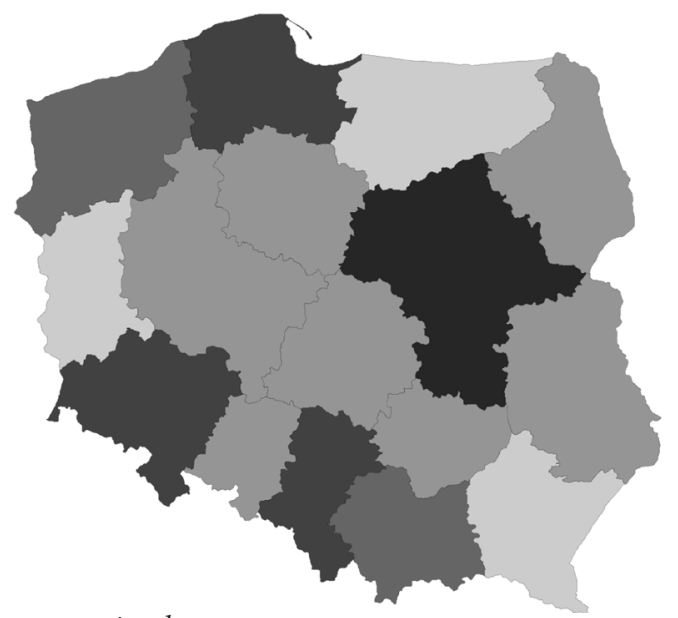

\section{Rysunek 2.}

\section{Poziom wynagrodzeń w Polsce w 2015 r.}

Źródło: opracowanie własne.

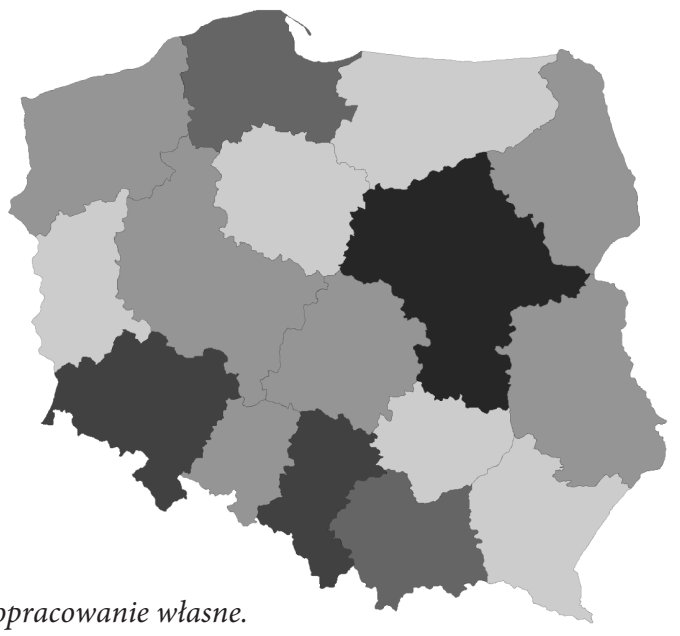




\section{ESTYMACJA PARAMETRÓW MODELU EKONOMETRYCZNEGO}

Jednym z głównych narzędzi używanych w ekonometrii jest model ekonometryczny, który jest formalną konstrukcją, gdzie za pomocą równania lub układów równań można przedstawić powiązania występujące między rozpatrywanymi zjawiskami ekonomicznymi (Adamczyk i in., 2009; Sobczyk, 2012). Często w definicji modelu ekonometrycznego podawana jest także teza, że model to uproszczone odwzorowanie rzeczywistości. Oznacza to, że uwzględnia on tylko pewne, najważniejsze elementy rzeczywistości, z pominięciem elementów mało istotnych (Kukuła, 2009). Zależności występujące wśród zjawisk ekonomicznych mają zazwyczaj bardzo złożony charakter. Mogą być także sprzężone (Rogut, Tokarski, 2007; Rokicki, 2007). Na zjawisko, które opisuje model, wpływa często wiele różnych czynników. Należy jednak zaznaczyć, że skutki i oddziaływanie jednych czynników będą silne i trwałe, przy zdecydowanie słabszym i nietrwałym wpływie innych. Warto uwzględniać także wpływ czynników losowych, mimo że występują sporadycznie i nieregularnie. Według zasad tworzenia modelu ekonometrycznego należy uwzględniać tylko główne czynniki, które mają znaczący wpływ na opisywane zjawisko, przy jednoczesnym pominięciu czynników słabo oddziałujących i czynników losowych (Kukuła, 2009; Barczak, Biolik, 2002). Celem modeli ekonometrycznych jest spełnienie czterech podstawowych zadań:

1) poznania i zrozumienia zależności występujących między podmiotami ekonomicznymi oraz całych układów gospodarczych,

2) systematyzacji i porządkowania informacji statystycznych, co pozwala na podział danych na długotrwałe trendy, wahania sezonowe i zaburzenia losowe,

3) testowania hipotez i założeń ekonomicznych,

4) prognozowania zjawisk występujących w ekonomii oraz prowadzenia analizy różnych polityk gospodarczych (Welfe, 2009). 
Model ekonometryczny jednorównaniowy można zapisać w postaci (Kukuła, 2009):

$$
Y=f\left(X_{1}, \ldots, X_{\mathrm{K}} ; \varepsilon\right)
$$

gdzie:

$Y$ - objaśniana zmienna, która reprezentuje modelowane zjawisko (zmienna endogeniczna),

$X_{1}, \ldots, X_{\mathrm{K}}$ - zmienne objaśniające,

$\varepsilon$ - zmienna losowa (nazywana także zakłóceniem losowym),

$f$ - postać analityczna modelu,

${ }_{\mathrm{K}}$ - liczba objaśniających zmiennych.

Zastosowanie zmiennej losowej w równaniu powoduje, że model ekonometryczny ma charakter stochastyczny. Relacja nieuwzględniająca zastosowania składnika losowego ma postać deterministyczną, która przyjmuje formę:

$$
Y=f\left(X_{1}, \ldots, X_{\mathrm{K}}\right)
$$

W powyższym równaniu symbol $Y$ oznacza zmienną zależną, a $X_{1}, \ldots, X_{\mathrm{K}}$ - zmienne niezależne.

W pierwszym opisywanym modelu występują zmienne objaśniające zamiast zmiennych niezależnych. Opisują one tworzenie się zmiennej objaśniającej (endogenicznej). Warto mieć na uwadze fakt, że występowanie zmiennej losowej $\varepsilon$ powoduje, że szacowanie na podstawie uzyskanych parametrów ma tylko przybliżony charakter (Kukuła, 2009).

Proces estymacji modelu ekonometrycznego polega na wyznaczeniu ocen parametrów strukturalnych (które są stałe, lecz nieznane), parametrów rozkładu składnika losowego i innych miar dopasowania modelu do obserwacji. Jedną z najczęściej używanych metod estymacji modeli jednorównaniowych jest metoda najmniejszych kwadratów. Polega ona na ustaleniu modelu, który opisuje zmienną objaśnianą $Y=\left(y_{\mathfrak{t}} ; t=1,2 \ldots, n\right)$ i $K$ zmiennych objaśniających $X_{1} \ldots, X_{\mathrm{K}}\left(x_{\mathrm{t} 1} \ldots, x_{\mathrm{tK}} ; t=1,2 \ldots, n\right)$ poprzez dopasowanie do nich hiperpłaszczyzny określonej wzorem:

$$
Y_{\mathrm{t}}=a_{0}+a_{1} X_{\mathrm{t} 1}+a_{2} X_{\mathrm{t} 2}+\ldots+a_{k} X_{t K}+\varepsilon_{t}
$$


Hiperpłaszczyzną dobraną za pomocą metody najmniejszych kwadratów jest taka, dla której suma kwadratów odchyleń obserwacji od hiperpłaszczyzny jest najmniejsza. Dopasowaną hiperpłaszczyznę określają wartości teoretyczne $\hat{y}_{\mathrm{t}}$, czyli wielkości, w których nieznane wartości $\left(a_{0}+a_{K}\right)$ zostały zastąpione ich ocenami $a_{0}+a_{\mathrm{K}}$ :

$$
\hat{\mathrm{y}}_{t}=a_{0}+a_{1} X_{\mathrm{t} 1}+a_{1} X_{\mathrm{t} 2}+\ldots+a_{k} X_{t K}
$$

a reszty $\left(e_{t}\right)$ to odchylenia wartości teoretycznych od obserwacji (wartości empirycznych) (Kufel, 2011):

$$
e_{t}=y_{t}+\hat{y}_{t}
$$

Do oceny dokładności dopasowania oszacowanego modelu do obserwacji można użyć trzech współczynników: współczynnika zmienności resztowej ${ }^{1}$, współczynnika zbieżności² oraz współczynnika determinacji (Kukuła, 2009; Maddala, 2006).

Dla każdego województwa został stworzony osobny podrozdział w celu wyraźniejszego ukazania różnic wynikających między danym województwem a innymi oraz w relacji do całego kraju.

Przeciętne miesięczne wynagrodzenie brutto (tabela 2) dla województwa dolnośląskiego w roku 2002 kształtowało się na poziomie 2163,57 zł. Wyższe średnie wynagrodzenia odnotowano w województwach mazowieckim, pomorskim i śląskim. Było ono także nieznacznie niższe od średniej krajowej, wynoszącej w 2002 r. 2239,56 zł. Na przestrzeni czternastu obserwowanych lat wynagrodzenie w województwie dolnośląskim wzrosło o 2040,67 zł, osiągając w 2015 r. wartość 4204,24 zł. Pod względem wzrostu wynagrodzenia w ciągu obserwowanego okresu, województwo dolnośląskie ustępuje jedynie województwu mazowieckiemu. W tabeli 3 przedstawiono estymację parametrów strukturalnych funkcji modelu ekonometrycznego dla województwa dolnośląskiego. 
Tabela 3.

Estymacja klasycznej metody najmniejszych kwadratów dla województwa dolnośląskiego

\begin{tabular}{|c|c|c|c|c|c|}
\hline & Wspólczynnik & Bląd stand. & t-Studenta & wartość p & \\
\hline Const. & $-11,3339$ & 0,47141 & $-24,0425$ & $<0,0001$ & $* * *$ \\
\hdashline Zmienna zależna (Y): time & 0,00599728 & 0,00014681 & 40,8507 & $<0,0001$ & $* * *$ \\
\hline Wsp. determ. R-kwadrat & 0,989531 & \multicolumn{2}{c}{ Skorygowany R-kwadrat } & 0,992265 \\
\hline
\end{tabular}

Źródło: opracowanie własne.

Ocena współczynnika wskazuje, że wzrost wynagrodzeń w skali kraju o 1 zł spowoduje wzrost wynagrodzeń w województwie dolnośląskim o 0,59 zł. Ocenę dopasowania modelu oparto na współczynniku determinacji R-kwadrat, którego wartość oznacza, że użyta funkcja regresji w 99,28\% wyjaśnia kształtowanie się poziomu wynagrodzeń.

$\mathrm{Na}$ przestrzeni obserwowanych czternastu lat wynagrodzenia wzrosły w województwie kujawsko-pomorskim o wartość 1586,86 zł, osiągając w 2015 r. wartość 3540,25 zł. Przeciętne miesięczne wynagrodzenie brutto osiągane w roku 2015 stanowiło 181,24\% wynagrodzenia z 2002 r. Średnie wynagrodzenie brutto dla województwa kujawsko-pomorskiego (2704,76 zł) wskazuje, iż mieszkańcy tego województwa uzyskiwali jedną z najniższych średnich wartości. W tabeli 4 przedstawiono estymację parametrów strukturalnych funkcji modelu ekonometrycznego dla województwa kujawsko-pomorskiego.

Tabela 4.

Estymacja klasycznej metody najmniejszych kwadratów dla województwa kujawsko-pomorskiego

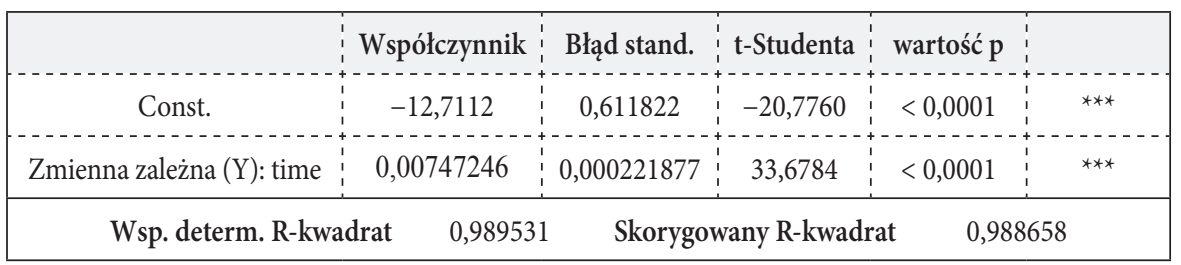

Źródło: opracowanie własne. 
Ocena współczynnika wskazuje, że wzrost wynagrodzeń w skali kraju o 1 zł spowoduje wzrost wynagrodzeń w województwie kujawsko-pomorskim o 0,74 zł. Ocenę dopasowania modelu oparto na współczynniku determinacji R-kwadrat, którego wartość oznacza, że użyta funkcja regresji w 98,95\% wyjaśnia kształtowanie się poziomu wynagrodzeń.

Wartość wynagrodzenia dla województwa lubelskiego była w 2002 r. o prawie 300 zł niższa niż średnia krajowa. W badanych latach w województwie lubelskim stwierdzono średnią wartość wynagrodzenia na poziomie 2798,96 zł, co także w skali kraju nie jest zbyt imponującym wynikiem. W tabeli 5 przedstawiono estymację parametrów strukturalnych funkcji modelu ekonometrycznego dla województwa lubelskiego.

Tabela 5.

Estymacja klasycznej metody najmniejszych kwadratów dla województwa lubelskiego

\begin{tabular}{|r|c|c|c|c|c|}
\hline & Wspókczynnik & Bład stand. & t-Studenta & wartość p & \\
\hline Const. & $-10,8789$ & 0,652442 & $-16,6742$ & $<0,0001$ & $* *$ \\
\hdashline Zmienna zależna (Y): time & 0,00656634 & 0,000227763 & 28,8297 & $<0,0001$ & ${ }^{* * *}$ \\
\hline Wsp. determ. R-kwadrat & 0,985768 & Skorygowany R-kwadrat & 0,984582 \\
\hline
\end{tabular}

Źródto: opracowanie własne.

Ocena współczynnika wskazuje, że wzrost wynagrodzeń w skali kraju o 1 zł spowoduje wzrost wynagrodzeń w województwie lubelskim o 0,65 zł. Ocenę dopasowania modelu oparto na współczynniku determinacji R-kwadrat, którego wartość oznacza, że użyta funkcja regresji w 98,57\% wyjaśnia kształtowanie się poziomu wynagrodzeń.

W tabeli 6 przedstawiono estymację parametrów strukturalnych funkcji modelu ekonometrycznego dla województwa lubuskiego.

Tabela 6.

Estymacja klasycznej metody najmniejszych kwadratów dla województwa lubuskiego

\begin{tabular}{|r|c|c|c|c|c|}
\hline & Współczynnik & Bląd stand. & t-Studenta & wartośćp & \\
\hline Const. & $-11,6365$ & 0,610605 & $-19,0573$ & $<0,0001$ & $* * *$ \\
\hline Zmienna zależna (Y): time & 0,0072196 & 0,000225471 & 32,0201 & $<0,0001$ & $* * *$ \\
\hline Wsp. determ. R-kwadrat & 0,988613 & Skorygowany R-kwadrat & 0,987665 \\
\hline
\end{tabular}

Źródło: opracowanie własne. 
Ocena współczynnika wskazuje, że wzrost wynagrodzeń w skali kraju o 1 zł spowoduje wzrost wynagrodzeń w województwie lubuskim o 0,73 zł. Ocenę dopasowania modelu oparto na współczynniku determinacji R-kwadrat, którego wartość oznacza, że użyta funkcja regresji w 98,86\% wyjaśnia kształtowanie się poziomu wynagrodzeń.

W 2002 r. województwo łódzkie zajmowało dziesiąte miejsce w Polsce pod względem wartości przeciętnego miesięcznego wynagrodzenia z kwotą 1966,22 zł. W okresie czternastu badanych lat wynagrodzenie w tym województwie osiągnęło wartość 2807,21 zł. W tabeli 7 przedstawiono estymację parametrów strukturalnych funkcji modelu ekonometrycznego dla województwa łódzkiego.

Tabela 7.

Estymacja klasycznej metody najmniejszych kwadratów dla województwa łódzkiego

\begin{tabular}{|c|c|c|c|c|c|}
\hline & Wspólczynnik & Bląd stand. & t-Studenta & wartóś p & \\
\hline Const. & $-10,8108$ & 0,629503 & $-17,1735$ & $<0,0001$ & $* * *$ \\
\hdashline Zmienna zależna (Y): time & 0,00652279 & 0,000219069 & 29,7751 & $<0,0001$ & $* * *$ \\
\hline Wsp. determ. R-kwadrat & 0,986645 & Skorygowany R-kwadrat & 0,985532 \\
\hline
\end{tabular}

Źródło: opracowanie własne.

Ocena współczynnika wskazuje, że wzrost wynagrodzeń w skali kraju o 1 zł spowoduje wzrost wynagrodzeń w województwie łódzkim o 0,65 zł. Ocenę dopasowania modelu oparto na współczynniku determinacji R-kwadrat, którego wartość oznacza, że użyta funkcja regresji w 98,66\% wyjaśnia kształtowanie się poziomu wynagrodzeń.

W tabeli 8 przedstawiono estymację parametrów strukturalnych funkcji modelu ekonometrycznego dla województwa małopolskiego.

Tabela 8.

Estymacja klasycznej metody najmniejszych kwadratów dla województwa małopolskiego

\begin{tabular}{|c|c|c|c|c|c|}
\hline & Współczynnik & Błąd stand. & t-Studenta & wartość p & \\
\hline Const. & $-11,9036$ & 0,544537 & $-21,8601$ & $<0,0001$ & $* * *$ \\
\hline Zmienna zależna (Y): time & 0,00664149 & 0,000182522 & 36,3874 & $<0,0001$ & $* * *$ \\
\hline Wsp. determ. R-kwadrat & 0,991018 & \multicolumn{2}{c|}{ Skorygowany R-kwadrat } & 0,990270 \\
\hline
\end{tabular}

Źródto: opracowanie własne. 
Ocena współczynnika wskazuje, że wzrost wynagrodzeń w skali kraju o 1 zł spowoduje wzrost wynagrodzeń w województwie małopolskim o 0,66 zł. Ocenę dopasowania modelu oparto na współczynniku determinacji R-kwadrat, którego wartość oznacza, że użyta funkcja regresji w 99,1\% wyjaśnia kształtowanie się poziomu wynagrodzeń.

Średnia wartość wynagrodzenia w badanych czternastu latach wynosi dla województwa mazowieckiego 3979,08 zł, co jest najlepszym wynikiem w skali kraju, znacząco odbiegającym od średniej dla całego kraju (3163,17 zł).

W tabeli 9 przedstawiono estymację parametrów strukturalnych funkcji modelu ekonometrycznego dla województwa mazowieckiego.

Tabela 9.

Estymacja klasycznej metody najmniejszych kwadratów dla województwa mazowieckiego

\begin{tabular}{|c|c|c|c|c|c|}
\hline & Wspólczynnik & Błąd stand. & t-Studenta & wartość p \\
\hline Const. & $-14,213$ & 0,728162 & $-19,5191$ & $<0,0001$ & $* * *$ \\
\hdashline Zmienna zależna (Y): time & 0,00545681 & 0,000179962 & 30,3220 & $<0,0001$ & $* * *$ \\
\hline Wsp. determ. R-kwadrat & 0,987116 & \multicolumn{2}{c}{ Skorygowany R-kwadrat } & 0,986043 \\
\hline
\end{tabular}

Źródło: opracowanie własne.

Ocena współczynnika wskazuje, że wzrost wynagrodzeń w skali kraju o 1 zł spowoduje wzrost wynagrodzeń w województwie mazowieckim o 0,54 zł.

Estymację parametrów strukturalnych funkcji modelu ekonometrycznego dla województwa opolskiego przedstawiono w tabeli 10 .

Tabela 10.

Estymacja klasycznej metody najmniejszych kwadratów dla województwa opolskiego

\begin{tabular}{|c|c|c|c|c|c|}
\hline & Wspólczynnik & Błąd stand. & t-Studenta & wartość p & \\
\hline Const. & $-12,1455$ & 0,648934 & $-18,7161$ & $<0,0001$ & $*$ \\
\hdashline Zmienna zależna (Y): time & 0,00687042 & 0,000222369 & 30,8965 & $<0,0001$ & ${ }^{* * *}$ \\
\hline Wsp. determ. R-kwadrat & 0,987585 & \multicolumn{2}{c|}{ Skorygowany R-kwadrat } & 0,986551 \\
\hline
\end{tabular}

Źródło: opracowanie własne. 
Ocena współczynnika wskazuje, że wzrost wynagrodzeń w skali kraju o 1 zł spowoduje wzrost wynagrodzeń w województwie opolskim o 0,68 zł.

Ocenę dopasowania modelu oparto na współczynniku determinacji R-kwadrat, którego wartość oznacza, że użyta funkcja regresji w 98,75\% wyjaśnia kształtowanie się poziomu wynagrodzeń.

Podczas całego badanego okresu średnie przeciętne miesięczne wynagrodzenie w województwie podkarpackim wynosiło 2560,63 zł. Jest to ostatni wynik w kraju, znacząco odbiegający od średniej, która wynosiła 3163,17 zł. W tabeli 11 przedstawiono estymację parametrów strukturalnych funkcji modelu ekonometrycznego dla województwa podkarpackiego.

Tabela 11.

Estymacja klasycznej metody najmniejszych kwadratów dla województwa podkarpackiego

\begin{tabular}{|c|c|c|c|c|c|}
\hline & Współczynnik & Błąd stand. & t-Studenta & wartość p & \\
\hline $\begin{array}{c}\text { Const. } \\
\text { Zmienna zależna (Y): time }\end{array}$ & 0,0072196 & 0,000225471 & 32,0201 & $<0,0001$ & $* * *$ \\
\hline Wsp. determ. R-kwadrat & 0,988431 & \multicolumn{2}{c|}{ Skorygowany R-kwadrat } & 0,987467 \\
\hline
\end{tabular}

Źródło: opracowanie własne.

Ocenę dopasowania modelu oparto na współczynniku determinacji $R^{2}$, którego wartość oznacza, że użyta funkcja regresji w 98,84\% wyjaśnia kształtowanie się poziomu wynagrodzeń.

W badanych czternastu latach można zaobserwować w województwie podlaskim średnią wartość wynagrodzenia na poziomie 2779,34 zł, co pozwala uznać to województwo za nieznacznie odbiegające od średniej wartości dla całego kraju. W tabeli 12 przedstawiono estymację parametrów strukturalnych funkcji modelu ekonometrycznego dla województwa podlaskiego.

Tabela 12.

Estymacja klasycznej metody najmniejszych kwadratów dla województwa podlaskiego

\begin{tabular}{|c|c|c|c|c|c|}
\hline & Współczynnik & Błąd stand. & t-Studenta & wartość p & \\
\hline Const. & $-12,0128$ & 0,607482 & $-19,7747$ & $<0,0001$ & $* * *$ \\
\hline Zmienna zależna (Y): time & 0,00702065 & 0,000214099 & 32,7916 & $<0,0001$ & $* * *$ \\
\hline Zmienna zależna (Y): time & 0,988963 & \multicolumn{3}{c|}{ Skorygowany R-kwadrat } & 0,988044 \\
\hline
\end{tabular}

Źródło: opracowanie własne. 
Ocena współczynnika wskazuje, że wzrost wynagrodzeń w skali kraju o 1 zł spowoduje wzrost wynagrodzeń w województwie podlaskim o 0,70 zł. Ocenę dopasowania modelu oparto na współczynniku determinacji R-kwadrat, którego wartość oznacza, że użyta funkcja regresji w 98,89\% wyjaśnia kształtowanie się poziomu wynagrodzeń.

Średni poziom wynagrodzenia w latach 2002-2015 wynosi dla województwa pomorskiego 3141,29 zł, więc jest bardzo zbliżony do średniej krajowej wynoszącej dla tego okresu kwotę 3163,17 zł. W tabeli 13 przedstawiono estymację parametrów strukturalnych funkcji modelu ekonometrycznego dla województwa pomorskiego.

Tabela 13.

Estymacja klasycznej metody najmniejszych kwadratów dla województwa pomorskiego

\begin{tabular}{|c|c|c|c|c|c|}
\hline & Wspólczynnik & Bląd stand. & t-Studenta & wartość p & \\
\hdashline Const. & $-12,0526$ & 0,512272 & $-23,5278$ & $<0,0001$ & ${ }^{* * *}$ \\
\hdashline Zmienna zależna (Y): time & 0,00622439 & 0,000159743 & 38,9650 & $<0,0001$ & ${ }^{* * *}$ \\
\hline Wsp. determ. R-kwadrat & 0,992158 & \multicolumn{2}{c|}{ Skorygowany R-kwadrat } & 0,991505 \\
\hline
\end{tabular}

Źródło: opracowanie własne.

Ocena współczynnika wskazuje, że wzrost wynagrodzeń w skali kraju o 1 zł spowoduje wzrost wynagrodzeń w województwie pomorskim o 0,62 zł.

Ocenę dopasowania modelu oparto na współczynniku determinacji R-kwadrat, którego wartość oznacza, że użyta funkcja regresji w 99,21\% wyjaśnia kształtowanie się poziomu wynagrodzeń.

W tabeli 14 przedstawiono estymację parametrów strukturalnych funkcji modelu ekonometrycznego dla województwa śląskiego.

Tabela 14.

Estymacja klasycznej metody najmniejszych kwadratów dla województwa śląskiego

\begin{tabular}{|c|c|c|c|c|c|}
\hline & Współczynnik & Błąd stand. & t-Studenta & wartość p & \\
\hline Const. & $-12,2815$ & 0,68123 & $-18,0284$ & $<0,0001$ & ${ }^{* * *}$ \\
\hdashline Zmienna zależna (Y): time & 0,00607534 & 0,000205063 & 29,6267 & $<0,0001$ & ${ }^{* * *}$ \\
\hline Zmienna zależna (Y): time & 0,986513 & \multicolumn{3}{l|}{ Skorygowany R-kwadrat } & 0,985389 \\
\hline
\end{tabular}

Źródło: opracowanie własne. 
Ocena współczynnika wskazuje, że wzrost wynagrodzeń w skali kraju o 1 zł spowoduje wzrost wynagrodzeń w województwie śląskim o 0,60zł.

Ocenę dopasowania modelu oparto na współczynniku determinacji R-kwadrat, którego wartość oznacza, że użyta funkcja regresji w 98,65\% wyjaśnia kształtowanie się poziomu wynagrodzeń.

W tabeli 15 przedstawiono estymację parametrów strukturalnych funkcji modelu ekonometrycznego dla województwa świętokrzyskiego.

Tabela 15.

Estymacja klasycznej metody najmniejszych kwadratów dla województwa świętokrzyskiego

\begin{tabular}{|c|c|c|c|c|c|}
\hline & Współczynnik & Błąd stand. & t-Studenta & wartość p & \\
\hline Const. & $-12,6151$ & 0,750255 & $-16,8145$ & $<0,0001$ & $* * *$ \\
\hline Zmienna zależna (Y): time & 0,00734053 & 0,000268532 & 27,3358 & $<0,0001$ & $*$ \\
\hline Wsp. determ. R-kwadrat & 0,984195 & \multicolumn{2}{c|}{ Skorygowany R-kwadrat } & 0,982878 \\
\hline
\end{tabular}

Źródło: opracowanie własne.

Ocena współczynnika wskazuje, że wzrost wynagrodzeń w skali kraju o 1 zł spowoduje wzrost wynagrodzeń w województwie świętokrzyskim o 0,73 zł.

Ocenę dopasowania modelu oparto na współczynniku determinacji R-kwadrat, którego wartość oznacza, że użyta funkcja regresji w 98,41\% wyjaśnia kształtowanie się poziomu wynagrodzeń.

Wynagrodzenie otrzymywane w 2015 r. w województwie warmińsko-mazurskim stanowiło 179,42\% wynagrodzenia uzyskiwanego w roku 2002, zaś średnia wartość wynagrodzenia osiąganego w latach 2002-2015 wyniosła 2663,27 zł. W tabeli 16 przedstawiono estymację parametrów strukturalnych funkcji modelu ekonometrycznego dla województwa warmińsko-mazurskiego.

Tabela 16.

Estymacja klasycznej metody najmniejszych kwadratów dla województwa warmińsko-mazurskiego

\begin{tabular}{|r|c|c|c|c|c|}
\hline & Wspólczynnik & Błąd stand. & t-Studenta & wartość p & \\
\hline Const. & $-12,6914$ & 0,708453 & $-17,9143$ & $<0,0001$ & $* * *$ \\
\hline Zmienna zależna (Y): time & 0,00758144 & 0,000260931 & 29,0554 & $<0,0001$ & $* * *$ \\
\hline Wsp. determ. R-kwadrat & 0,985985 & Skorygowany R-kwadrat & 0,984817 \\
\hline
\end{tabular}

Źródło: opracowanie własne. 
Ocena współczynnika wskazuje, że wzrost wynagrodzeń w skali kraju o 1 zł spowoduje wzrost wynagrodzeń w województwie warmińsko-mazurskim o $0,75 \mathrm{zl}$.

Ocenę dopasowania modelu oparto na współczynniku determinacji R-kwadrat, którego wartość oznacza, że użyta funkcja regresji w 98,59\% wyjaśnia kształtowanie się poziomu wynagrodzeń.

W pierwszym roku analizowanego okresu przeciętne miesięczne wynagrodzenie brutto w województwie wielkopolskim wynosiło 2047,58 zł. W tabeli 17 przedstawiono estymację parametrów strukturalnych funkcji modelu ekonometrycznego dla tego województwa.

Tabela 17.

Estymacja klasycznej metody najmniejszych kwadratów dla województwa wielkopolskiego

\begin{tabular}{|c|c|c|c|c|c|}
\hline & Współczynnik & Błąd stand. & t-Studenta & wartość p & \\
\hline Const. & $-12,6486$ & 0,692705 & $-18,2597$ & $<0,0001$ & $* * *$ \\
\hline Zmienna zależna (Y): time & 0,0070276 & 0,000236974 & 29,6556 & $<0,0001$ & $*$ \\
\hline Wsp. determ. R-kwadrat & 0,986539 & Skorygowany R-kwadrat & 0,985417 \\
\hline
\end{tabular}

Źródto: opracowanie własne.

Ocena współczynnika wskazuje, że wzrost wynagrodzeń w skali kraju o 1 zł spowoduje wzrost wynagrodzeń w województwie wielkopolskim o 0,70 zł.

Ocenę dopasowania modelu oparto na współczynniku determinacji R-kwadrat, którego wartość oznacza, że użyta funkcja regresji w 98,65\% wyjaśnia kształtowanie się poziomu wynagrodzeń.

Przeciętne miesięczne wynagrodzenie brutto w roku 2002 dla województwa zachodniopomorskiego wynosiło 2068,44 zł. Wynagrodzenie otrzymywane w tym województwie w 2015 r. stanowi 183,41\% przeciętnego miesięcznego wynagrodzenia uzyskiwanego w pierwszym roku badanego okresu. Jest to wynik nieznacznie odbiegający od średniej krajowej, wynoszącej 185,34\%. Średni poziom miesięcznego wynagrodzenia w województwie zachodniopomorskim w okresie 2002-2015 wynosi 2890,55 zł.

W tabeli 18 przedstawiono estymację parametrów strukturalnych funkcji modelu ekonometrycznego dla województwa zachodniopomorskiego. 
Tabela 18.

Estymacja klasycznej metody najmniejszych kwadratów dla województwa zachodniopomorskiego

\begin{tabular}{|c|c|c|c|c|c|}
\hline & Współczynnik & Błąd stand. & t-Studenta & wartość p & \\
\hline Const. & $-12,5812$ & 0,620534 & $-20,2748$ & $<0,0001$ & $* * *$ \\
\hline Zmienna zależna (Y): time & 0,00694721 & 0,000210523 & 32,9998 & $<0,0001$ & $* * *$ \\
\hline Wsp. determ. R-kwadrat & 0,989101 & \multicolumn{2}{c|}{ Skorygowany R-kwadrat } & 0,988192 \\
\hline
\end{tabular}

Źródło: opracowanie własne.

Ocena współczynnika wskazuje, że wzrost wynagrodzeń w skali kraju o 1 zł spowoduje wzrost wynagrodzeń w województwie zachodniopomorskim o $0,69 \mathrm{zł}$.

Ocenę dopasowania modelu oparto na współczynniku determinacji R-kwadrat, którego wartość oznacza, że użyta funkcja regresji w 98,91\% wyjaśnia kształtowanie się poziomu wynagrodzeń.

\section{Podsumowanie}

Poziom przeciętnego wynagrodzenia w Polsce w ujęciu wojewódzkim w badanym okresie 2002-2015 ulegał dużym zmianom. Na podstawie wyników estymacji stworzonego modelu ekonometrycznego można stwierdzić, że funkcja trendu potwierdza tendencję wzrostową badanego zjawiska, co objawia się w postaci wzrostu przeciętnego miesięcznego wynagrodzenia dla każdego województwa, w każdym roku obserwacji. Wzrost przeciętnego wynagrodzenia dla każdego z województw był na różnym poziomie, lecz bardzo zbliżonym w skali kraju. Najniższa wartość relacji wynagrodzenia z 2015 r. do roku 2002 wystąpiła w województwie mazowieckim, gdzie wynosiła 176,05\%. Może wydawać się nienaturalny fakt, że w województwie o najwyższym poziomie wynagrodzeń na przestrzeni każdego roku analizy wystąpił najniższy poziom wzrostu wynagrodzeń. Najwyższym wzrostem wynagrodzenia na przestrzeni badanych czternastu lat może pochwalić się województwo dolnośląskie, gdzie wynagrodzenie z 2015 r. stanowiło 194,32\% wynagrodzenia osiąganego w pierwszym roku analizy. Średnia dla całego kraju wynosiła $185,34 \%$. 
Wysokie wartości współczynnika determinacji R-kwadrat dla każdego z województw świadczą o właściwym dopasowaniu modelu do danych empirycznych. Wartość tego współczynnika nie wyniosła dla żadnego z województw poniżej 98\%. Potwierdza to podobny poziom wzrostu wynagrodzeń na poziomie wojewódzkim.

\section{Literatura}

Adamczyk, A., Tokarski, T., Włodarczyk, R. (2009). Przestrzenne zróżnicowanie płac w Polsce, „Gospodarka Narodowa” Nr 20(9), s. 87-109. ISSN 2300-5238.

Barczak, A.S., Biolik, J. (2002). Podstawy ekonometrii, Katowice: Wydawnictwo Akademii Ekonomicznej. ISBN 838726587X.

Borkowska, S. (2004). Strategie wynagrodzeń, Kraków: Oficyna Ekonomiczna. ISBN 8389355345.

Czajka, Z. (2009). Zarządzanie wynagrodzeniami w Polsce, Warszawa: Polskie Wydawnictwo Ekonomiczne. ISBN 9788320818055.

Gruszczyński, M., Podgórska, M. (2004). Ekonometria, Warszawa: Szkoła Główna Handlowa - Oficyna Wydawnicza. ISBN 9788386689528.

Jacukowicz, Z. (2010). Refleksje nad polityka wynagradzania w Polsce, Warszawa: Instytut Pracy i Spraw Socjalnych. ISBN 9788361125327.

Kostera, M. (2000). Zarządzanie personelem, Warszawa: Polskie Wydawnictwo Ekonomiczne. ISBN 9788320819175.

Król, H., Ludwiczyński, A. (2014). Zarzadzanie zasobami ludzkimi. Tworzenie kapitału ludzkiego organizacji, Warszawa: Wydawnictwo Naukowe PWN. ISBN 9788301148133.

Kufel, T. (2011). Ekonometria. Rozwiązywanie problemów z wykorzystaniem programu GRETL, Warszawa: Wydawnictwo Naukowe PWN. ISBN 9788301165130.

Kukuła, K. (2009). Wprowadzenie do ekonometrii, Warszawa: Wydawnictwo Naukowe PWN. ISBN 9788301156718.

Maddala, G.S. (2006). Ekonometria, Warszawa: Wydawnictwo Naukowe PWN. ISBN 9788301146382.

Nowakowski, E. (2011). Podstawy ekonometrii z elementami algebry liniowej, Warszawa: Wszechnica Polska Szkoła Wyższa TWP. ISBN 9788389077158.

Rogut, A., Tokarski, T., (2007). Determinanty regionalnego zróżnicowania płac w Polsce, „Ekonomista” Nr 1, s. 75-88. ISSN 0013-3205. 
Rokicki, B. (2007). Regionalna konwergencja płac w Polsce w okresie integracji z Unia Europejską. W: J.J. Michałek, W. Siwiński, M.W. Socha (red.), Polska w Unii Europejskiej. Dynamika konwergencji ekonomicznej, Warszawa: Wydawnictwa Naukowe PWN. ISBN 9788301150495.

Sekuła, Z. (2013). Struktury wynagradzania pracowników, Warszawa: Wolters Kluwer Polska. ISBN 9788326444517.

Sobczyk, M. (2012). Ekonometria, Warszawa: Wydawnictwo C.H. Beck. ISBN 9788325543440 .

Welfe, A. (2009). Ekonometria. Metody i ich zastosowanie, Warszawa: Polskie Wydawnictwo Ekonomiczne. ISBN 9788320817676.

Witkowska, D. (2012). Podstawy ekonometrii i teorii prognozowania, Warszawa: Wolters Kluwer Polska. ISBN 9788326438691.

Zając, Cz. (2007). Zarządzanie zasobami ludzkimi, Poznań: Wydawnictwo Wyższej Szkoły Bankowej. ISBN 9788372052476.

\section{Endnotes}

${ }^{1} V_{\varepsilon}=\frac{S_{e}}{\bar{y}} \times 100$ (Współczynnik zmienności resztowej informuje badacza, jaką częścią średniej wartości zmiennej endogenicznej są odchylenia o charakterze losowym). ${ }^{2} \varphi^{2}=\frac{(n-k) S_{\epsilon}^{2}}{\sum_{t=1}^{n}\left(y^{t}-\bar{y}\right)^{2}} \quad$ (Wartości współczynnika zbieżności wahają się w przedziale $[0 ; 1]$. Im bliżej zera znajduje się wartość współczynnika, tym wartości teoretyczne są bardziej zgodne z wartościami zaobserwowanymi. Współczynnik zbieżności równy jeden oznacza złe dobranie zmiennych objaśniających oraz brak skorelowania).

${ }^{3}$ Informuje on, jaka część zmienności zmiennej endogenicznej została wyjaśniona za pomocą modelu. 